World Sustainability Forum 2014 - Conference Proceedings Paper

\title{
Electricity Production from Anaerobic Digestion of Animal Slurries in Farm Scale Plants
}

\author{
Jacopo Bacenetti ${ }^{1, *}$ and Marco Fiala ${ }^{1}$ \\ ${ }^{1}$ Department of Agricultural and Environmental Sciences. Production, Landscape, Agroenergy. \\ University of Milan/ Via Giovanni Celoria 2, 20133, Milan, Italy \\ E-Mails: jacopo.bacenetti@unimi.it; marco.fiala@unimi.it \\ * Author to whom correspondence should be addressed; Tel.: +39-02-503-16869; Fax: +39-02-503- \\ 16845
}

Received: 29 September 2014 / Accepted: 21 October 2014 / Published: 1 November 2014

\begin{abstract}
Currently, in Italy, more than 1200 agricultural biogas plants are running, mainly in the northern regions. At the end of 2012, 1.65\% of the Italian electric consumption was produced from agricultural biogas plants. The public incentives framework for electricity production from biogas has been updated by the D.M. of 6 July 2012: the highest value is granted to AD plants with electrical power $<300 \mathrm{~kW}$ and mainly fed with by-products. Specific economic bonuses are provided for heat valorization and nitrogen reduction in the digestate. Nevertheless, with regard to agricultural AD plants, remarkable environmental impacts could be due to biomass production as well as to digestate management. On the other hand, benefits could arise from electricity and heat generation from renewable sources and mineral fertilization substitution. The aim of this study is to assess the environmental profile of electricity production from four different AD plant mainly fed with animal slurry and electrical power lower than $300 \mathrm{~kW}$. Using LCA method, the environmental performance of electricity production from biogas has been evaluated using $1 \mathrm{kWh}$ of electricity as functional unit. All processes involved as well as the processes avoided by the biogas production system (e.g. electricity and thermal energy production) were included in the system boundaries and therefore evaluated. The most critical stages (environmental hotspots) were identified and discussed; mitigation strategies of the environmental burdens where evaluated too. Moreover, the outcomes of the environmental assessment were compared with the environmental impact related to the Italian electricity mix. The achieved
\end{abstract}


results show that the electricity produced from the AD plant has better environmental performances than electricity produced from fossil fuels in particular for impact categories such as global warming and fossil depletion. Moreover, the recovery and the valorization of surplus heat reduce significantly the environmental burdens. Definitely, livestock slurries are a good feedstock for $\mathrm{AD}$ plants from an environmental point of view thanks to credits provided by a suitable waste management as well as to the absence of environmental burdens related to their production. The logistic aspects of the biomass supply must be carefully evaluated because the transportation of the feedstock over long distances can offset the environmental benefits due to the replacement of energy generation from fossil fuels.

Keywords: biogas; life cycle assessment; renewable energy.

\section{Introduction}

The European policy concerning renewable energy has set a goal for supplying $20 \%$ of the European energy demand from renewable energy sources by 2020 [4]. An important part of the renewable energy will originate gaseous, liquid and solid biofuels using biomass as a raw material.

The interest on the biogas production for bioenergy generation (electricity and heat) is increasing since it provides a clean and decentralized source of energy from renewable feedstock (Lijo et al., 2014). Moreover, biogas production involves the production of a valuable co-product such as digestate, a stream rich in nutrients which could be used as an organic fertilizer for crop cultivation in substitution of mineral fertilizers (De Vries et al., 2012).

Currently, in Italy, more than 1200 agricultural biogas plants are running, mainly in the northern regions. At the end of 2012, agricultural biogas plants produced about $1.65 \%$ of the Italian electric consumption (Bacenetti et al., 2013).

The public-incentives-framework for electricity (EE) production from biogas has been updated by the D.M. of July $6^{\text {th }}, 2012$ : the highest value is granted to AD plants with electrical power $<300 \mathrm{~kW}$ and mainly fed with by-products. Specific economic bonuses are provided for heat valorization and nitrogen reduction in the digestate.

Although biogas production arises as a cleaner and environmental safe alternative for energy production, it is important to quantify the environmental impacts associated to this process (Dressler et al., 2012; Lijó et al, 2014a; Lijó et al, 2014b). Life Cycle Assessment (LCA) is an internationally accepted method to gain insight into the environmental consequences of a product or system (ISO 14040, 2006). This methodology has been widely used to assess the environmental profile of bioenergy production systems and numerous studies can be found in the literature (Dressler et al., 2012; Hartmann, 2006; Jury et al., 2010; Lansche and Müller, 2012). In these studies, bioenergy systems provide good opportunities to achieve environmental benefits when fossil fuels are replaced or when they are compared with conventional waste management (Börjesson and Berglund, 2007; De Vries et al., 2012). However, it is interesting to highlight that the environmental performance of a bioenergy system from biogas is considerably affected by the feedstock considered, the final use of the biogas and the digestate management (Poeschl et al., 2012a; b). 
The aim of this study is to assess the environmental profile of electricity production from four different AD plants mainly fed with animal slurry and electrical power lower than $300 \mathrm{~kW}$.

\section{Materials and Methods}

\subsection{Methods}

Life Cycle Assessment (LCA) is a methodology to assess the potential environmental impacts and resources' consumption associated with a production system (ISO 14040, 2006). LCA methodology was chosen to perform the environmental analysis in this study, following the principles reported in ISO standards (ISO 14040, 2006).

Using the LCA method, the environmental performance of electricity production from biogas has been evaluated using $1 \mathrm{kWh}$ of electricity as functional unit.

As concerns the system boundary, both all the processes involved and the processes avoided by the biogas production system (e.g. electricity and thermal energy production) were included within the system boundary, and therefore evaluated. The most critical stages (environmental hotspots) were identified and discussed; mitigation strategies of the environmental burdens were evaluated as well. Moreover, the outcomes of the environmental assessment were compared with the environmental impact related to the Italian electricity mix. The environmental impact of Italian electric mix was taken from Ecoinvent (Ecoinvent, 2012).

Among the steps defined within the life cycle impact assessment phase of the standardized LCA methodology, only classification and characterization stages were undertaken (ISO 14040, 2006). The characterization factors reported by the ILCD method were used. The following impact potentials were evaluated according to the selected method: climate change (CC), ozone depletion (OD), particulate matter (PM); photochemical oxidant formation (POF); acidification (TA), freshwater eutrophication (FE), terrestrial eutrophication (TE) marine eutrophication (ME), and mineral, fossil and renewable resource Depletion (MFRD). The software SimaPro 7.3 was used for the computational implementation of the inventories (Goedkoop et al., 2010). Due to the uncertainties about the definition of characterization factors for many active ingredients, the toxicity-related impact categories were not evaluated (Sleeswikk et al.; 2008).

\subsection{Materials}

The environmental burdens of four different agricultural anaerobic digestion plants were evaluated. All the plants are located in Northern Italy and are fed mainly with animal slurry and manure; Table 1 shows the main characteristics of the $4 \mathrm{AD}$ plants. Two plants (A and B) digest only animal slurries, while the two others plants (C and D) codigest animal slurry and maize silage. Table 2 reports the characteristics of the different feedstock digested in the plants.

In all the AD plants, digestate is stored in open tanks. Therefore, methane emissions and ammonia emissions take place. They are assumed at $8.9 \mathrm{~kg} / \mathrm{MWh}$ for methane and $0.23 \mathrm{~kg} / \mathrm{MWh}$ for ammonia (Whiting and Azapagic, 2014). As regard to the heat cogenerated by the CHP engine, besides the thermal self-consumption, only plant A uses a share of this energy. In more details, for $2 \mathrm{~h} /$ day it is 
used for hot water production while, from October $15^{\text {th }}$ to March $15^{\text {th }}$, it is used (12 h/day) to heat farm buildings (farmer house, offices, etc.). The surplus heat valorized offsets the production of the same thermal energy by a natural gas boiler.

Table 1. Main characteristics of the biogas plants.

\begin{tabular}{|c|c|c|c|c|c|}
\hline & \multicolumn{4}{|c|}{ Biogas plant } \\
\hline & & $\mathbf{A}$ & B C & & D \\
\hline District & Unit & Cremona & Lodi & Pavia & Cremona \\
\hline Electrical power & $\mathrm{kW}$ & 100 & 250 & 300 & 300 \\
\hline Starting year & - & 2013 & 2010 & 2013 & 2013 \\
\hline Feeding rate ri] $^{[1]}$ & t/day & CS 40 t/day & PS 180 t/day & $\begin{array}{l}\text { CS } 35 \text { t/day } \\
\text { MS } 13 \text { t/day }\end{array}$ & $\begin{array}{l}\text { PS } 45 \text { t/day } \\
\text { MS } 14 \text { t/day }\end{array}$ \\
\hline $\begin{array}{l}\text { Electric self } \\
\text { consumption }\end{array}$ & $\%$ & 7.0 & 7.6 & 9.2 & 8.4 \\
\hline Transport Distance & $\mathrm{km}$ & 0.1 & 3.5 & $\begin{array}{l}1.5 \text { for CS } \\
0.8 \text { for MS }\end{array}$ & $\begin{array}{l}1.3 \text { for } \mathrm{PS} \\
0.7 \text { for } \mathrm{MS}\end{array}$ \\
\hline
\end{tabular}

${ }^{[1]} \mathrm{CS}=$ cow slurry; PS = pig slurry: MS = maize silage

Table 2. Feedstock characteristics.

\begin{tabular}{|c|c|c|c|}
\cline { 2 - 4 } \multicolumn{1}{c|}{} & Total solid & $\begin{array}{c}\text { Specific biogas } \\
\text { production }\end{array}$ & Methane \\
\hline Feedstock & $\%_{\mathrm{WB}}$ & $\mathrm{m}^{3} / \mathrm{t}_{\mathrm{DM}}$ & $\% \mathrm{vol}$ \\
\hline Cow slurry & $8.0 \%$ & 325 & $56 \%$ \\
\hline Pig slurry & $3.5 \%$ & 450 & $56 \%$ \\
\hline Maize silage & $33.0 \%$ & 600 & $52 \%$ \\
\hline
\end{tabular}

\section{Results and Discussion}

The environmental load for the electricity generated in the biogas plants is reported in Table 3. Those plants fed with animal slurries (A and B) show better environmental performances than plants $(\mathrm{C}$ and $\mathrm{D})$ that codigest also maize silage.

Among the different biogas plants, the plant A produces electricity with the lowest environmental impact: thanks to the heat-valorization credits, for 3 (OD, FE and MFRD) of the 9 assessed impact categories, environmental benefits are achieved. Although totally fed with pig slurry, plant B has, for CC and MFRD, a high environmental load due to the transport of a big feedstock mass. For all the assessed impact categories, plant B shows higher environmental loads than plant B.

Compared to the plants that digest slurries, plants (C and D) fed also with maize silage show a considerably higher impact for AC, TE, FE and ME: the fertilizer applications during maize cultivation involve emissions of ammonia in the air as well as nitrogen leaching and phosphate losses (run-off and leaching). Plant C, fed with pig slurry and maize silage, has the worst results for all the nine impact categories. 
Table 3. Environmental impact of electricity from AD plants.

\begin{tabular}{|l|l|r|r|r|r|c|}
\hline \multicolumn{1}{|c|}{ Impact category } & \multicolumn{1}{|c|}{ Unit } & Plant A & Plant B & Plant C & Plant D & $\begin{array}{c}\text { EE mix } \\
\text { ITA }\end{array}$ \\
\hline Climate change & kg CO eq & $1,70 \mathrm{E}-01$ & $3,16 \mathrm{E}-01$ & $3,06 \mathrm{E}-01$ & $3,43 \mathrm{E}-01$ & $6,51 \mathrm{E}-01$ \\
\hline Ozone depletivo & kg CFC-11 eq & $-1,31 \mathrm{E}-08$ & $7,95 \mathrm{E}-09$ & $5,08 \mathrm{E}-09$ & $9,26 \mathrm{E}-09$ & $5,76 \mathrm{E}-08$ \\
\hline Particulate matter & kg PM2.5 eq & $2,55 \mathrm{E}-05$ & $5,19 \mathrm{E}-05$ & $1,24 \mathrm{E}-04$ & $1,51 \mathrm{E}-04$ & $2,26 \mathrm{E}-04$ \\
\hline Photochemical ozone formation & kg NMVOC eq & $1,80 \mathrm{E}-04$ & $5,70 \mathrm{E}-04$ & $4,86 \mathrm{E}-04$ & $7,83 \mathrm{E}-04$ & $1,68 \mathrm{E}-03$ \\
\hline Acidification & molc H+ eq & $8,66 \mathrm{E}-04$ & $1,24 \mathrm{E}-03$ & $4,88 \mathrm{E}-03$ & $5,44 \mathrm{E}-03$ & $3,56 \mathrm{E}-03$ \\
\hline Terrestrial eutrophication & molc N eq & 3,48E-03 & $4,71 \mathrm{E}-03$ & $2,17 \mathrm{E}-02$ & $2,40 \mathrm{E}-02$ & $5,72 \mathrm{E}-03$ \\
\hline Freshwater eutrophication & kg P eq & $-5,85 \mathrm{E}-08$ & $9,59 \mathrm{E}-07$ & $1,64 \mathrm{E}-05$ & $1,86 \mathrm{E}-05$ & $6,52 \mathrm{E}-07$ \\
\hline Marine eutrophication & kg N eq & $5,46 \mathrm{E}-05$ & $1,67 \mathrm{E}-04$ & $2,76 \mathrm{E}-04$ & $3,81 \mathrm{E}-04$ & $5,11 \mathrm{E}-04$ \\
\hline Mineral, fossil\&ren resource depl. & kg Sb eq & $-3,63 \mathrm{E}-08$ & $1,77 \mathrm{E}-06$ & $8,22 \mathrm{E}-07$ & $2,56 \mathrm{E}-06$ & $3,31 \mathrm{E}-07$ \\
\hline
\end{tabular}

Figure 1 shows the environmental load for the electricity produced by the different biogas plants and the comparison with the Italian electric mix. For 5 impact categories (CC, OD, PM, POF and ME), the Italian electricity has a higher environmental impact than electric energy from AD plants; however, for AC, TE, FE it has a lower impact than EE from the AD plants (C and D) fed with maize silage. $\mathrm{AC}$, TE and FE, impact categories related to the emission of nitrogen compounds, are higher than for the Italian electricity mix for biogas plants fed with maize silage (C and D); this is due to organic and mineral fertilizations needed for maize cultivation. During digestate application, ammonia emissions takes place while, following nitrogen application, nitrate leaching occurs. The worst performances of plant $\mathrm{D}$ compared to plant $\mathrm{C}$ are due to: i) higher maize silage utilization; ii) the transport of a largest amount of animal slurry $(52.5 \mathrm{t} \cdot \mathrm{km} /$ day in plant $\mathrm{C}$ and $58.5 \mathrm{t} \cdot \mathrm{km} /$ day in plant $\mathrm{D})$

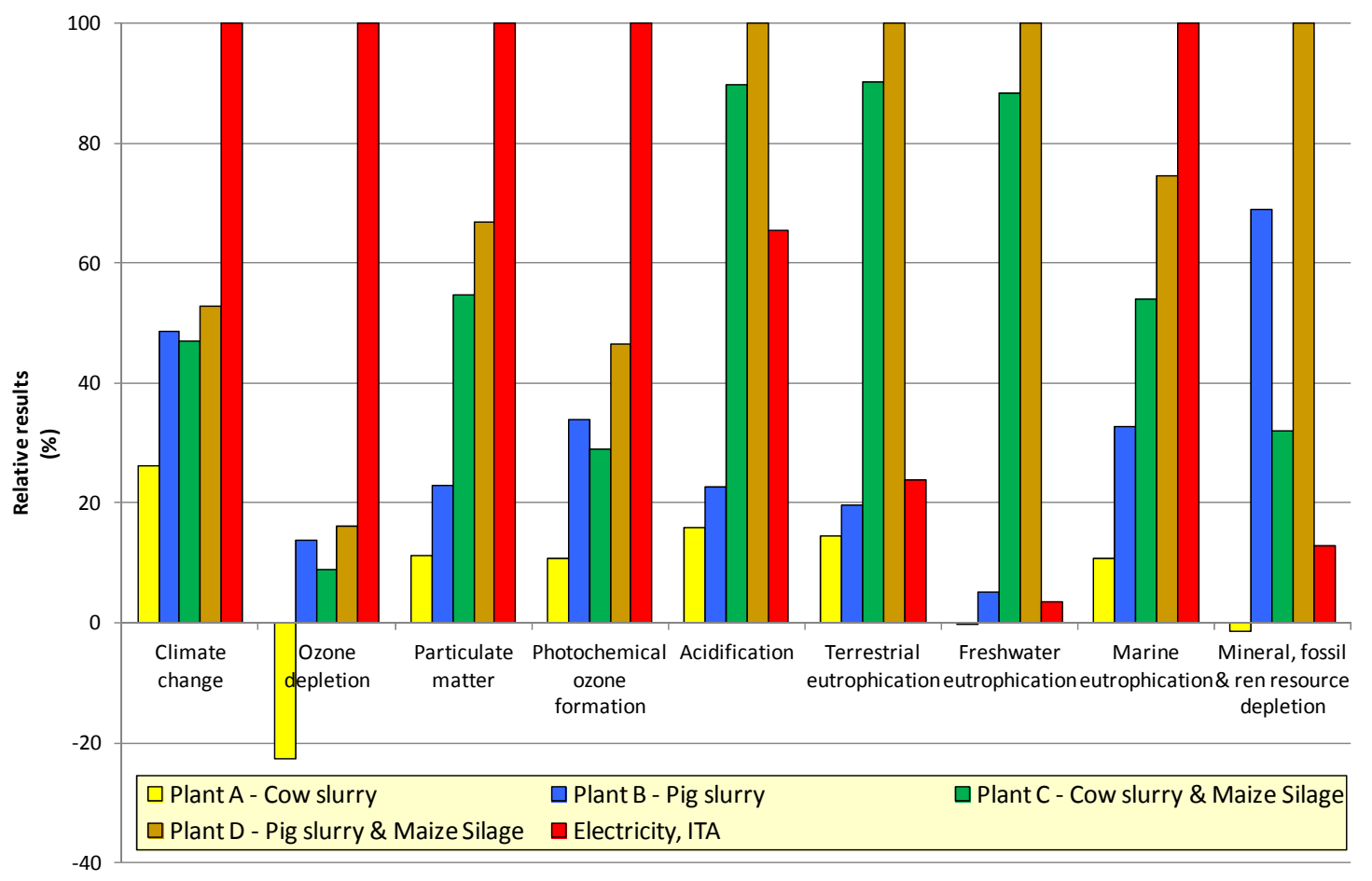

Figure 1. Comparison among the environmental impact of electricity produced in the four different biogas plants and in the Italian electric mix. 


\section{Conclusions}

The electricity produced from the AD plants fed with animal slurry has better environmental performances than electricity produced from fossil fuels, whereas for AD plants fed with maize silage this is true only for those impact categories not related to ammonia and dinitrogen monoxide emissions and to nitrate and phosphate leaching. The use of maize silage as feedstock involves a high environmental impact for acidification and eutrophication impact categories.

Moreover, recovery and valorization of surplus heat (Plant A) significantly reduce the environmental burdens. Livestock slurries are a good feedstock for AD plants from an environmental point of view, thanks to credits provided by a suitable waste management as well as to the absence of environmental burdens related to their production. Logistic aspects of the biomass supply must be carefully evaluated because transporting the feedstock over long distances can offset the environmental benefits due to the replacement of energy generation from fossil fuels.

\section{Acknowledgments}

The authors thank Regione Lombardia which financed a Postdoctoral Research Fellowship (“Progetto Dote Ricerca” financed by FSE - Regione Lombardia).

\section{References and Notes}

1. Bacenetti, J., Negri, M., Fiala, M., Gonzalez Garcia S. Anaerobic digestion of different feedstock: impact on energetic and environmental balances of biogas process, Science of the Tota $l$ Environment 2013, 463-464, 541-551.

2. Börjesson, P., Berglund, M. Environmental systems analysis of biogas systems - Part II: The environmental impact of replacing various reference systems. Biomass and Bioenergy 2007, 31, 326-344.

3. De Vries, J.W., Groenestein, C.M., De Boer, I.J.M. Environmental consequences of processing manure to produce mineral fertilizer and bio-energy. Journal of Environmental Management 2012, 102, 173-183.

4. Dressler D., Loewen A., Nelles M. Life cycle assessment of the supply and use of bioenergy: impact of regional factors on biogas production. The International Jour nal of Life Cycle Assessment, 2012, 17 (9), 1104-1115.

5. European Parliament and of the Council. Directive 2009/28/EC on the promotion of the use of energy from renewable sources. Official Journal of the European Union, 2009 L 140/16.

6. Goedkoop, M., de Schryver, A., Oele, M., Durksz, S., de Roest, D., 2010. Introduction to LCA with SimarPro 7. PRé Consultants, the Netherlands.

7. Hartmann, J.K., Life-cycle-assessment of industrial scale biogas plants. 2006. University of Goettingen, Germany.

8. ISO 14040, 2006. Environmental Management - Life Cycle Assessment - Principles and Framework.

9. Jury, C., Benetto, E., Koster, D., Schmitt, B., Welfring, J.. Life Cycle Assessment of biogas production by monofermentation of energy crops and injection into the natural gas grid. Biomass and Bioenergy 2010, 34, 54-66. 
10. Lansche, J., Müller, J., 2012. Life cycle assessment of energy generation of biogas fed combined heat and power plants: Environmental impact of different agricultural substrates. Engineering in Life Sciences. 2012, 13, No. 3, 313-320.

11. Lijó, L., González-García, S., Bacenetti, J., Fiala, M., Feijoo, G., Lema, J.M., Moreira, M.T.. Life Cycle Assessment of electricity production in Italy form anaerobic co-digestion of pig slurry and energy crops, Renewable Energy 2014, 68, 625-635.

12. Lijó, L., González-García, S., Bacenetti, J., Fiala, M., Feijoo, G., Moreira, M.T. Assuring the sustainable production of biogas from anaerobic mono-digestion, Journal of Cleaner Production 2014, 72, 23-34.

13. Poeschl, M., Ward, S., Owende, P. Environmental impacts of biogas deployment - Part I: life cycle inventory for evaluation of production process emissions to air. Journal of Cleaner Production. 2012a, 24, 168-183.

14. Poeschl, M., Ward, S., Owende, P. Environmental impacts of biogas deployment - Part II: life cycle assessment of multiple production and utilization pathways. Journal of Cleaner Production. 2012b, 24, 184-201.

15. Sleeswijk, A.W., van Oers, L., Guinée, G., Struijs, J., Huijbregts, M. Normalisation in product life cycle assessment: An LCA of the global and European economic systems in the year 2000. Science of the Total Environment 2008, 390, 227 - 240.

16. Whiting, A., Azapagic, A. Life cycle environmental impacts of generating electricity and heat from biogas produced by anaerobic digestion. Energy 2014, 70, 181-193.

(C) 2014 by the authors; licensee MDPI, Basel, Switzerland. This article is an open access article distributed under the terms and conditions of the Creative Commons Attribution license. 